\title{
Economic Analysis of Coal Gasification Plant for Electricity and Thermal Energy Supplies in Indonesia
}

\author{
Prima Zuldian, Suneerat Fukuda, and M. Djoni Bustan
}

\begin{abstract}
Development of coal gasification plants in Indonesia for electricity and thermal energy supplies has been started officially since 2011 . So far, two gasification technologies have been selected for demonstration, including two-stage updraft fixed-bed (Plant A) and twin-fire fixed bed gasifier technologies (Plant B). Economic analysis for electricity generation cost, selling price (with achieve ROI $=11 \%$ and 4 year loan installment) and tariff (with transmission cost added) as well as syngas generation cost and selling price was conducted based on these two technologies. The calculated electricity generation cost are 0.189 and $0.204 \mathrm{US} \$ / \mathrm{kWh}$, electricity selling price are 0.273 and $0.352 \mathrm{US} \$ / \mathrm{kWh}$ and electricity tariff are 0.279 and $0.358 \mathrm{US} \$ / \mathrm{kWh}$ for Plant $A$ and $B$, respectively. Thermal energy is supplied as synthetic gas (syngas). The calculated syngas generation cost are 0.322 and $0.340 \mathrm{US} \$ / \mathrm{Nm}^{3}$ and syngas selling price are 0.38 and $0.512 \mathrm{US} \$ / \mathrm{Nm}^{3}$, for Plant $A$ and $B$, respectively. The analysis also shows that, based on the studied scenario, the selling prices of electricity from coal gasification are competitive when compared to that from diesel oil (i.e. 0.375 US $\$ / \mathrm{kWh}$ ) but much less competitive when compared to that natural gas (i.e. $0.0864 \mathrm{US} \$ / \mathbf{k W h}$ ). The selling prices of syngas is also higher than that of Liquefied Petroleum Gas (LPG) (i.e. 0.238 US\$/ $\mathrm{Nm}^{3}$ ).
\end{abstract}

Index Terms - Indonesia, gasifier technologies, electricity prices, syngas prices.

\section{INTRODUCTION}

Indonesia has the second largest of coal reserve in South and Central Asia, which is mostly found in Sumatra and Kalimantan Islands. Currently, coal is the major fuel for electricity supply with the share of $71 \%$ in 2011 and is expected to help increase the electrification ratio of $78 \%$ in 2013 to $95 \%$ in 2025 [1], [2]. This target is supported by the government policy to add the value of coal and promote its domestic use.

Due to shortage and price fluctuation of natural gas for electricity generation and Liquefied Petroleum Gas (LPG) for thermal energy generation, abundant coal resource has become a promising alternative fuel. Moreover, the restriction of mining-product import including coal has already been implemented causing coal upgrading process an obligation. One of the upgrading methods is coal gasification [3].

Coal gasification is a promising technology for small- and

Manuscript received October 9, 2015; revised March 9, 2016.

P. Zuldian and Suneerat Fukuda are with the Joint Graduate School of Energy and Environment, King Mongkut's University of Technology Thonburi, Bangkok 10140 Thailand (e-mail: prima_zuldian@yahoo.com, suneerat@jgsee.kmutt.ac.th).

M. D. Bustan is with Graduate School for Chemical Engineering Program, University of Sriwijaya, South Sumatera, Indonesia (e-mail: djajashanta@yahoo.co.id). medium-scale power plants due to its potentially high efficiency as compared to centralized coal combustion power plants. According to the plan of Indonesian Government, ten coal gasification power plants with the capacity of $8 \mathrm{MW}$ each will be built in ten locations across Indonesia, especially in remote areas where electricity demand is low. Sumatera and Kalimantan islands, where mainly 6-20 kV transmission lines are available, were selected [4].

So far, two gasification technologies have been selected for demonstration in Indonesia, including two-stage updraft fixed-bed and twin-fire fixed bed gasifier. The schematic diagrams of the gasifiers are presented in Fig. 1. In the two-stage updraft fixed-bed gasifier, syngas is produced with a counter current flow of coal and air resulting in the syngas output in two streams. The gasifier efficiency can achieve $87 \%$ while the overall efficiency for power generation is $17 \%$, higher than the conventional updraft gasifier with one stream syngas output [5]. The twin-fire fixed bed gasifier uses multi-air injection automatically controlled to supply and distribute air to achieve optimal reaction when reacting with coal. This gasifier efficiency can achieve $85 \%$ while the overall efficiency for power generation is $24 \%$ [5].

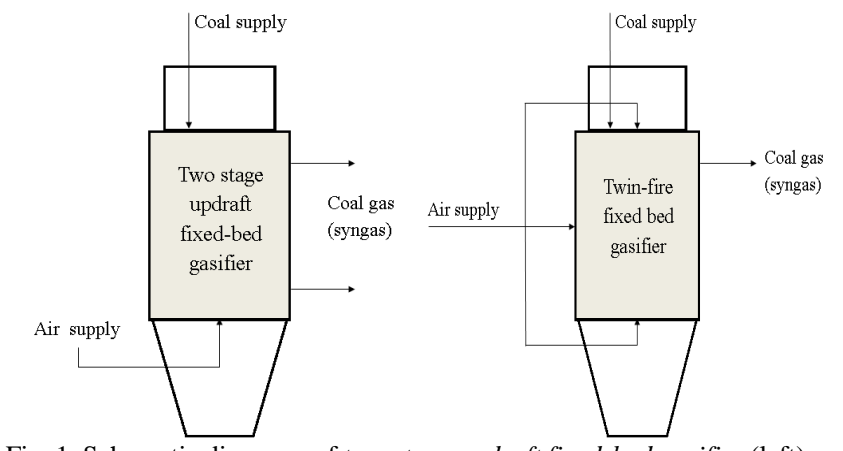

Fig. 1. Schematic diagrams of two-stage updraft fixed-bed gasifier (left) and twin-fire fixed bed gasifier (right).

\section{MethodOLOGY}

This study focuses on the economic analysis of coal gasification plant for electricity generation and synthesis gas (syngas) generation purpose with the capacity of $8 \mathrm{MW}$ electricity generation or equivalent thermal energy generation. The analysis was based on two-stage updraft fixed-bed gasifier technology (Plant A) and twin-fire fixed bed gasifier technology (Plant B) to compare their economic feasibility. The technical specification and equipment cost of the gasifier were collected or estimated based on the information from the existing coal gasification power plants in Indonesia to determine capital expenditures (CAPEX), operational expenditures (OPEX). Then economics analysis including profitability analysis (e.g. installment cost, annual cash flow), 
the length time return of capital (e.g. installment, payout time), the total accumulative of capital (e.g. Net Profit Over Total Life Time of Project (NPOTLP), Total Capital Sink (TCS)), return investment (e.g. Return on Investment (ROI), Discounted Cash Flow Rate of Return (DCF-ROR), Break Even Point) and price analysis (e.g. electricity \& syngas prices) were conducted.

The following assumptions were applied throughout the analysis in this paper:

- The plant operated for 365 days per year, and service life for 20 years [5].

- All calculation used 2011 as the base year when coal gasification projects for energy supply was started commercially in Indonesia.

- Both Plant A and Plant B used the same fuels which was bituminous coal with calorific value of $6,150 \mathrm{kcal} / \mathrm{kg}$. Based on the "Coal Price Standard" published by Indonesian MEMR, the average coal selling price in 2011 was 112.8 US\$/ton [5].

- The calculation of Equipment Cost in CAPEX was based on the following:

- Official information from the $6 \mathrm{MW}$ Chinese Coal Gasification Power Plant scaled up to $8 \mathrm{MW}$, assumed as Plant A, using two-stage updraft fixed-bed gasifier technology in Riau Province [6].

- Official information from the $6 \mathrm{MW}$ German Coal Gasification Power Plant scaled up to $8 \mathrm{MW}$, assumed as Plant B, using twin-fire fixed bed gasifier technology in Tayan, West Kalimantan Province [7].

- Calculation for the $8 \mathrm{MW}$ plant was made by means of exponential and index price of equipment from existing plant data and other engineering references.

- The coal consumption was $7,670 \mathrm{~kg} / \mathrm{hr}$ for two-stage updraft fixed-bed and $5,727 \mathrm{~kg} / \mathrm{hr}$ for twin-fire fixed bed gasifiers [5].

- All of the equipment was imported. The freight charge was $6 \%$ of total purchased equipment.

- Financial source for CAPEX came from $40 \%$ bank loan and $60 \%$ from savings.

- Water consumption was free of charge.

- Density of syngas was assumed the same for both technologies.

- Income tax was $30 \%$ of non-tax revenue [8].

- Coal transportation was by truck with average distance of 75 miles and the cost was calculated using equations as stated by Indonesian MEMR [9], [10].

- Total land area for each technology was $40,000 \mathrm{~m}^{2}$. The building area was $5,300 \mathrm{~m}^{2}$ for two-stage updraft fixed-bed gasifier and $3,025 \mathrm{~m}^{2}$ for twin-fire fixed bed gasifier [5].

- Generated electricity was used for required plant own consumption, while electricity consumption for plant producing syngas relied on purchased electricity.

- Depreciation was determined by using a linear relationship method [8].

- Indonesian Electricity and Consumer price indices in 2000-2013 were used to determine OPEX and price forecast for electricity and thermal supplies, respectively [11].

- The calculation of the share of percentages on CAPEX
\& OPEX components are determined by using other engineering references.

- Capacity charge or transmission cost is $0.006 \mathrm{US} \$ / \mathrm{kWh}$, which follows information from Indonesian Electricity State Enterprise Area Sanggau, West Kalimantan Province.

- Return on Investment (ROR) is fixed at $11 \%$.

- Installment period is 4 years with $4 \%$ annual interest.

- Electricity generation and syngas generation used the same plant capacity factor, i.e. $90 \%$.

\section{RESULTS AND DISCUSSION}

\section{A. Equipment Cost}

Similar for both technologies, the major plant components are shown in Table I. Scaling up cost from the capacity of 6 MW to 8 MW for the base year 2011 was obtained by using (1) [12]. Where $(C x \& I x),(C y \& I y)$ are the price and price index of equipment in 2011 and 2002, respectively.

$$
C x=C y\left[\frac{X 1}{X 2}\right]^{m}\left[\frac{I x}{I y}\right]
$$

The price index 2002 (Iy) was obtained from Marshall and Swift Index from 1989 to 2002. The price index and price equipment in 2002 were used to determine price index 2011(Ix) by using the least square method which was resulted by Eq. (2):

$$
Y=-32566.77429+16.82769231 X
$$

where $Y=I x$ and $X=2011, I x=1,274$. Meanwhile, $(X 1)$ and $(X 2)$ are equipment information for 8 and $6 \mathrm{MW}$ capacities, respectively. The cost capacity exponent $(\mathrm{m})$ is the value used for predicting the cost of scale-up equipment up to 10 times the capacity and the exponent values for each equipment are presented in Table I.

\begin{tabular}{clcc}
\multicolumn{2}{c}{ TABLE I: MAJOR COMPONENTS IN COAL GASIFICATION PlanT } \\
\hline \hline No. & \multicolumn{1}{c}{ Equipment } & Quantity & Exponent \\
\hline 1. & Fixed-bed gasifier [13] & 3 & 0.85 \\
\hline 2. & $\begin{array}{l}\text { Electrical 1 Tar Catcher } \\
\text { [14] }\end{array}$ & 1 & 0.74 \\
\hline 3. & Cyclone [14] & 1 & 0.61 \\
\hline 4. & Heat Exchanger [15] & 1 & 0.63 \\
\hline 5. & Air Cooler [15] & 1 & 0.69 \\
\hline 6. & Indirect Cooler [15] & 1 & 0.47 \\
\hline 7. & Electrical Oil Catcher [14] & 1 & 0.74 \\
\hline 8. & Desulfurizer I [15] & 1 & 0.75 \\
\hline 9. & Desulfurizer II [15] & 1 & 0.75 \\
\hline 10. & Gas Engine [15] & 9 & 0.84 \\
\hline 11. & Gas Storage [13] & 1 & 0.85 \\
\hline 12. & Blower [15] & 3 & 0.75 \\
\hline 13. & ID Fan [12] & 3 & 0.44 \\
\hline 14. & Pump [12] & 13 & 0.33 \\
\hline \hline
\end{tabular}

\section{B. CAPEX and OPEX Calculations}

The CAPEX and OPEX for the base year 2011 were determined based on real data and values from engineering references such as engineering handbooks, journals and 
publications, and are presented in Tables II and III, respectively.

The sum of direct and indirect cost, or so-called called fixed capital investment cost, is fixed at $90 \%$ of CAPEX, and the rest $10 \%$ is working capital.

For electricity generation, the total CAPEX for Plant A, which was imported from China, i.e. 15.99 million US\$, was much less than that for Plant B, which was imported Germany, i.e. 43.89 million US\$. However, the OPEX of the two plants were similar, i.e. 11.94 and 12.89 million for Plant A and Plant B, respectively.

The CAPEX for syngas generation plant were lower than that for electricity generation plant due to additional components related to downstream electricity generation, but the OPEX were slightly higher. The CAPEX for German gasifier technology was also higher, i.e. 14.61 and 42.83 million US\$, while OPEX were similar, i.e. 12.59 and 13.33 million US\$ for Plant A and B, respectively.

The resulted OPEX for electricity and syngas generation in 2011 were projected until the year 2030. As commonly used by Indonesian energy agencies, linear regression (shown as (3) and (4)) was selected to analyze electricity and consumer price indices 2000-2013 and resulted in the growth-OPEX rate in period 2011-2030 at 6\% and 5\% for Plant A and B, respectively.

$$
\begin{gathered}
Y=14.15525275 X-28148.49749 \\
Y=7.2052087791 X-14359.65501
\end{gathered}
$$

where:

$Y=$ Target electricity/consumer price index

$X=$ Initial electricity/consumer price index. The selected lowest growth-OPEX rate aims to minimize increasing electricity and thermal price fast.

\section{Economic Calculation}

Based on input data in Section II, economic calculation was conducted for electricity generation cost (EGC) and syngas generation cost (SGC) based on (5) and (6), respectively.

$$
\begin{aligned}
\mathrm{EGC} & =\frac{\mathrm{OPEX}}{\text { Capacity Factor } \times 8,000 \mathrm{~kW} \times 8,760 \mathrm{hr} / \text { year }} \\
\mathrm{SGC} & =\frac{\mathrm{OPEX}}{\text { Capacity Factor } \times 6,878,760 \mathrm{kcal} \times 8,760 \mathrm{hr} / \text { year }}
\end{aligned}
$$

The selling prices were obtained by trial and error method to achieve the Return on Investment (ROI) at $11 \%$ with 4 year installment period. This referred to similar type/scale of plants in Indonesia, e.g. small-scale steam power plant [17]. The electricity tariff was obtained from the sum of electricity selling price and transmission cost. All results were calculated based on 2011 and are summarized in Tables IV and V. The projection to 2030 was also made and is presented in Fig. 2 and Fig. 3, which shows a steady increase for all values.

\section{Competitiveness}

The selling prices of coal gasification products, both electricity and syngas, were compared with those from fossil fuel based, i.e. diesel oil and natural gas for electricity and LPG for syngas. The results clearly show that, based on the studied scenario and selling prices of the same products from fossil fuels [18], the selling prices of electricity from coal gasification are competitive when compared to that from diesel oil (i.e. $0.375 \mathrm{US} \$ / \mathrm{kWh}$ ) but much less competitive when compared to that natural gas (i.e. $0.0864 \mathrm{US} \$ / \mathrm{kWh}$ ). The selling prices of syngas is also higher than that of LPG (i.e. $0.238 \mathrm{US} \$ / \mathrm{Nm}^{3}$ ). However, one has to bear in mind that the baselines for these comparisons are different such as

\begin{tabular}{|c|c|c|c|}
\hline No. & Components & Plant A & Plant B \\
\hline I. & \multicolumn{3}{|c|}{ Capital Expenditures $($ CAPEX) $=a+b+c$} \\
\hline$a$ & \multicolumn{3}{|c|}{ Direct Cost $($ US \$ thousand $)=$ Total No.1.1 to 1.10} \\
\hline 1.1 & $\begin{array}{l}\text { Purchase equipment } \\
{[5]-[7],[12]-[15]}\end{array}$ & 4,242 & 29,509 \\
\hline 1.2 & Land cost [5],[12] & 363 & 363 \\
\hline 1.3 & Building cost [5],[12] & 376 & 215 \\
\hline 1.4 & $\begin{array}{l}\text { Equipment installation } \\
\text { [12] }\end{array}$ & 308 & 308 \\
\hline 1.5 & $\begin{array}{l}\text { Instrumentation \& control } \\
{[12]}\end{array}$ & 444 & 444 \\
\hline 1.6 & Piping cost [12] & 239 & 239 \\
\hline 1.7 & Electrical system [12],* & 105 & 105 \\
\hline 1.8 & Yard improvements [12] & 513 & 513 \\
\hline 1.9 & Service facilities[12] & 1,879 & 1,879 \\
\hline 1.10 & $\begin{array}{l}\text { Health, safety \& } \\
\text { environment [12] }\end{array}$ & 19 & 19 \\
\hline$b$. & $\begin{array}{l}\text { Indirect Cost (US \$ thousand } \\
1.15\end{array}$ & $=$ Total No & 1.11 to \\
\hline 1.11 & $\begin{array}{l}\text { Engineering \& } \\
\text { Supervision [12] } \\
\end{array}$ & 1,025 & 1,025 \\
\hline 1.12 & Legal expenses [12] & 814 & 814 \\
\hline 1.13 & $\begin{array}{l}\text { Construction expenses } \\
{[12]}\end{array}$ & 1,222 & 1,222 \\
\hline 1.14 & Contractor's Fee [12] & 814 & 814 \\
\hline 1.15 & Contingencies [12] & 2,036 & 2,036 \\
\hline$c$. & $\begin{array}{l}\text { Working Capital (US \$ thous } \\
\text { to } 1.19\end{array}$ & nd) = Total & No. 1.16 \\
\hline 1.16 & $\begin{array}{l}\text { Raw material in process } \\
{[5],[10]}\end{array}$ & 709 & 530 \\
\hline 1.17 & $\begin{array}{l}\text { Cash kept on hand for } \\
\text { monthly payment of } \\
\text { operating expenses } \\
{[10],[12], *}\end{array}$ & 105 & 97 \\
\hline 1.18 & Start-up cost* & 97 & 76 \\
\hline 1.19 & Accounts payable [12] & 688 & 3,686 \\
\hline & Total CAPEX & 15,998 & 43,893 \\
\hline II & Operational Expenditures (O & $E X)=d+e$ & $+f+g$ \\
\hline$d$ & $\begin{array}{l}\text { Variable Production Cost }(\text { US } \\
\text { Total } 2.1 \text { to } 2.6\end{array}$ & thousand/ & $e a r)=$ \\
\hline 2.1 & Raw materials [5], [10] & 8,617 & 6,434 \\
\hline 2.2 & Operating labor* & 124 & 124 \\
\hline 2.3 & $\begin{array}{l}\text { Operating supervision } \\
{[12]}\end{array}$ & 19 & 19 \\
\hline 2.4 & Utilities [6], [7],* & 0.4 & 0.4 \\
\hline 2.5 & $\begin{array}{l}\text { Maintenance \& repairs } \\
{[12]}\end{array}$ & 603 & 1,580 \\
\hline 2.6 & Operating supplies [12] & 91 & 237 \\
\hline$e$. & $\begin{array}{l}\text { Fixed Charge (US \$ thousan } \\
\text { to } 2.10\end{array}$ & year) $=$ Tot & l No. 2.7 \\
\hline 2.7 & Depreciation [8], [12],* & 450 & 1,923 \\
\hline 2.8 & $\begin{array}{l}\text { Tax for property [12], } \\
{[16]}\end{array}$ & 216 & 593 \\
\hline 2.9 & Financing for interest $*$ & - & - \\
\hline
\end{tabular}
production capacities, government subsidies, etc.

TABLE II: CAPEX AND OPEX CALCULATION ON COAL GASIFICATION PLANT FOR ELECTRICITY GENERATION (BASED ON 2011) 


\begin{tabular}{llcr}
\hline \hline 2.10 & Insurance [12] & 92 & 253 \\
\hline $\boldsymbol{f}$. & $\begin{array}{l}\text { Plant Overhead Cost (US } \\
\text { \$ thousand/year) }\end{array}$ & $\mathbf{1 6 1}$ & $\mathbf{1 6 1}$ \\
\hline $\boldsymbol{g}$ & $\begin{array}{l}\text { General Expenses (US \$ thousand/year) } \\
\text { 2.11 to 2.13 }\end{array}$ & Total No. \\
\hline 2.11 & $\begin{array}{l}\text { Administrative expenses } \\
\text { [12] }\end{array}$ & 21 & 21 \\
\hline 2.12 & $\begin{array}{l}\text { Distribution \& marketing } \\
\text { expenses [12] }\end{array}$ & 1,187 & 1,187 \\
\hline 2.13 & $\begin{array}{l}\text { Research \& development } \\
\text { expenses [12] }\end{array}$ & 356 & 356 \\
\hline & Total OPEX & $\mathbf{1 1 , 9 3 7}$ & $\mathbf{1 2 , 8 8 7}$ \\
\hline \hline
\end{tabular}

TABLE III: CAPEX AND OPEX CALCULATION ON COAL GASIFICATION PLANT FOR SYNGAS GENERATION (BASED ON 2011)

\begin{tabular}{|c|c|c|c|}
\hline No. & Components & Plant A & Plant B \\
\hline I. & \multirow{2}{*}{\multicolumn{3}{|c|}{$\begin{array}{l}\text { Capital Expenditures }(\text { CAPEX })=a+b+c \\
\text { Direct Cost }(\text { US } \$ \text { thousand })=\text { Total No.1.1 to } 1.10\end{array}$}} \\
\hline$a$ & & & \\
\hline 1.1 & $\begin{array}{l}\text { Purchase equipment } \\
{[5]-[7],[12]-[15]}\end{array}$ & 2,992 & 28,452 \\
\hline 1.2 & Land cost [5], [12] & 363 & 363 \\
\hline 1.3 & Building cost [5], [12] & 376 & 215 \\
\hline 1.4 & $\begin{array}{l}\text { Equipment installation } \\
\text { [12] }\end{array}$ & 308 & 308 \\
\hline 1.5 & $\begin{array}{l}\text { Instrumentation \& control } \\
{[12]}\end{array}$ & 444 & 444 \\
\hline 1.6 & Piping cost [12] & 239 & 239 \\
\hline 1.7 & Electrical system [12] & 103 & 103 \\
\hline 1.8 & Yard improvements [12] & 513 & 513 \\
\hline 1.9 & Service facilities[12] & 1,879 & 1,879 \\
\hline 1.10 & $\begin{array}{l}\text { Health, safety \& } \\
\text { environment [12] }\end{array}$ & 19 & 19 \\
\hline b. & \multicolumn{3}{|c|}{$\begin{array}{l}\text { Indirect Cost }(\text { US } \$ \text { thousand })=\text { Total No. } 1.11 \text { to } \\
1.15\end{array}$} \\
\hline 1.11 & $\begin{array}{l}\text { Engineering \& } \\
\text { Supervision [12] }\end{array}$ & 1,025 & 1,025 \\
\hline 1.12 & Legal expenses [12] & 814 & 814 \\
\hline 1.13 & $\begin{array}{l}\text { Construction expenses } \\
{[12]}\end{array}$ & 1,222 & 1,222 \\
\hline 1.14 & Contractor's Fee [12] & 814 & 814 \\
\hline 1.15 & Contingencies [12] & 2,036 & 2,036 \\
\hline c. & \multicolumn{3}{|c|}{$\begin{array}{l}\text { Working Capital (US \$ thousand })=\text { Total No. } 1.16 \\
\text { to } 1.19\end{array}$} \\
\hline 1.16 & $\begin{array}{l}\text { Raw material in process } \\
{[5],[10]}\end{array}$ & 709 & 530 \\
\hline 1.17 & $\begin{array}{l}\text { Cash kept on hand for } \\
\text { monthly payment of } \\
\text { operating expenses } \\
{[10],[12], *}\end{array}$ & 105 & 97 \\
\hline 1.18 & Start-up cost* & 97 & 76 \\
\hline 1.19 & Accounts payable [12] & 549 & 3,687 \\
\hline & Total CAPEX & 14,607 & 42,834 \\
\hline II & \multicolumn{3}{|c|}{ Operational Expenditures $($ OPEX $)=d+e+f+g$} \\
\hline$d$ & \multicolumn{3}{|c|}{$\begin{array}{l}\text { Variable Production Cost }(\text { US } \$ \text { thousand/year })= \\
\text { Total } 2.1 \text { to } 2.6\end{array}$} \\
\hline 2.1 & Raw materials [5],[10] & 8,617 & 6,434 \\
\hline 2.2 & Operating labor* & 124 & 124 \\
\hline 2.3 & $\begin{array}{l}\text { Operating supervision } \\
{[12]}\end{array}$ & 19 & 19 \\
\hline 2.4 & Utilities [6], [7],* & 758 & 507 \\
\hline 2.5 & $\begin{array}{l}\text { Maintenance and repairs } \\
\text { [12] }\end{array}$ & 603 & 1,580 \\
\hline 2.6 & Operating supplies [12] & 91 & 237 \\
\hline e. & \multicolumn{3}{|c|}{$\begin{array}{l}\text { Fixed Charge (US } \$ \text { thousand/year })=\text { Total No. } 2.7 \\
\text { to } 2.10\end{array}$} \\
\hline 2.7 & Depreciation [8], [12],* & 377 & 1,861 \\
\hline 2.8 & $\begin{array}{l}\text { Tax for property [12], } \\
{[16]}\end{array}$ & 197 & 593 \\
\hline 2.9 & Financing for interest $*$ & - & \\
\hline 2.10 & Insurance [12] & 84 & 253 \\
\hline
\end{tabular}

\begin{tabular}{llrr}
\hline \hline$f$. & $\begin{array}{l}\text { Plant Overhead Cost (US } \\
\text { \$ thousand/year) }\end{array}$ & $\mathbf{1 6 1}$ & $\mathbf{1 6 1}$ \\
\hline g. & $\begin{array}{l}\text { General Expenses (US \$ thousand/year) } \\
\text { 2.11 to 2.13 }\end{array}$ & Total No. \\
\hline 2.11 & $\begin{array}{l}\text { Administrative expenses } \\
{[12]}\end{array}$ & 21 & 21 \\
\hline 2.12 & $\begin{array}{l}\text { Distribution \& marketing } \\
\text { expenses [12] }\end{array}$ & 1,187 & 1,187 \\
\hline 2.13 & $\begin{array}{l}\text { Research \& development } \\
\text { expenses [12] }\end{array}$ & 356 & 356 \\
\hline & Total OPEX & $\mathbf{1 2 , 5 9 4}$ & $\mathbf{1 3 , 3 3 2}$ \\
\hline \hline
\end{tabular}

TABLE IV: ECONOMIC CALCULATION OF COAL GASIFICATION PLANT FOR ELECTRICITY GENERATION (BASED ON 2011)

\begin{tabular}{|c|c|c|c|}
\hline No & Parameters & $\begin{array}{c}\text { Plant } \\
\text { A }\end{array}$ & $\begin{array}{c}\text { Plant } \\
\text { B }\end{array}$ \\
\hline 1. & Profitability & & \\
\hline 1.1 & $\begin{array}{l}\text { The installment cost for loan } \\
\text { payment (\$/installment's year) } \\
\text { [17] }\end{array}$ & - & - \\
\hline 1.2 & Net profit before tax (\$/year) & 2,514 & 6,898 \\
\hline 1.3 & Net profit after tax (\$/year) [8] & 1,760 & 4,828 \\
\hline 1.4 & Annual Cash Flow (\$/year) & 1,760 & 4,828 \\
\hline 2. & The length time return of capital & & \\
\hline 2.1 & Payout Time (POT) (years) [17] & 8.55 & 8.55 \\
\hline 3. & The total accumulative of capital & or 20 yea & \\
\hline 3.1 & $\begin{array}{l}\text { Net Profit Over Total Life of } \\
\text { Project (NPOTLP) }(\$)\end{array}$ & 21,717 & 59,552 \\
\hline 3.2 & Total Capital Sink (TCS) (\$) & 28,145 & 77,218 \\
\hline 4. & Return on Investment & & \\
\hline 4.1 & $\begin{array}{l}\text { Rate of Return on Investment } \\
\text { (ROR) (\%) [17],[19] }\end{array}$ & $11 \%$ & $11 \%$ \\
\hline 4.2 & $\begin{array}{l}\text { Discounted Cash Flow Rate of } \\
\text { Return (DCF-ROR) (\%) [20] }\end{array}$ & $5.41 \%$ & $5.48 \%$ \\
\hline 4.3 & Break Even Point (BEP) & $50 \%$ & $39 \%$ \\
\hline 5. & Electricity Prices & & \\
\hline 5.1 & $\begin{array}{l}\text { Electricity Generation Cost } \\
(\$ / k W h)\end{array}$ & 0.189 & 0.204 \\
\hline 5.2 & Electricity Selling Price $(\$ / k W h)$ & 0.273 & 0.352 \\
\hline 5.3 & Electricity Tariff $(\$ / k W h)$ & 0.279 & 0.358 \\
\hline
\end{tabular}

TABLE V: ECONOMICS CALCULATION OF COAL GASIFICATION PLANT FOR SYNGAS GENERATION (BASED ON 2011)

\begin{tabular}{|c|c|c|c|}
\hline No & Parameters & $\begin{array}{c}\text { Plant } \\
\text { A }\end{array}$ & $\begin{array}{c}\text { Plant } \\
\text { B }\end{array}$ \\
\hline 1. & Profitability & & \\
\hline 1.1 & $\begin{array}{l}\text { The installment cost for loan } \\
\text { payment (\$/installment's year) } \\
{[17]}\end{array}$ & - & \\
\hline 1.2 & Net profit before tax (\$/year) & 2,295 & 6,731 \\
\hline 1.3 & Net profit after tax (\$/year) [8] & 1,607 & 4,712 \\
\hline 1.4 & Annual Cash Flow (\$/year) & 1,607 & 4,712 \\
\hline 2. & The length time return of capital & & \\
\hline 2.1 & Payout Time (POT) (years) [17] & 8.55 & 8.75 \\
\hline 3. & \multicolumn{3}{|c|}{ The total accumulative of capital for 20 years } \\
\hline 3.1 & $\begin{array}{l}\text { Net Profit Over Total Life of } \\
\text { Project (NPOTLP) }(\$)\end{array}$ & 19,831 & 58,215 \\
\hline 3.2 & Total Capital Sink (TCS) (\$) & 25,698 & 75,355 \\
\hline 4. & Return on Investment & & \\
\hline 4.1 & $\begin{array}{l}\text { Rate of Return on Investment } \\
(\text { ROR) (\%) [17],[19] }\end{array}$ & $11 \%$ & $11 \%$ \\
\hline 4.2 & $\begin{array}{l}\text { Discounted Cash Flow Rate of } \\
\text { Return (DCF-ROR) (\%) [20] }\end{array}$ & $5.40 \%$ & $5.49 \%$ \\
\hline 4.3 & Break Even Point (BEP) & $51 \%$ & $40 \%$ \\
\hline 5. & Syngas Prices & & \\
\hline 5.1 & Syngas Generation Cost $\left(\$ / \mathrm{Nm}^{3}\right)$ & 0.322 & 0.340 \\
\hline 5.2 & Selling Price of Syngas $\left(\$ / \mathrm{Nm}^{3}\right)$ & 0.380 & 0.512 \\
\hline
\end{tabular}

Remark: Data for these components were obtained from direct information survey in Indonesia. 


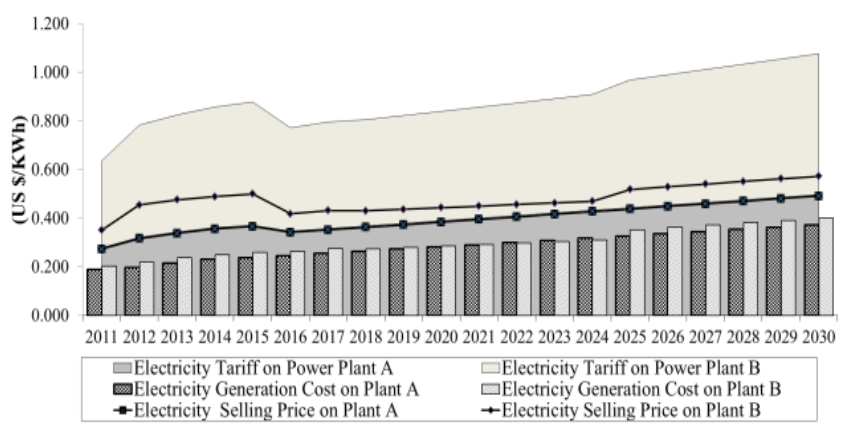

Fig. 2. Electricity generation cost, electricity selling price and electricity tariff on Plant A and Plant B in period 2011-2030.

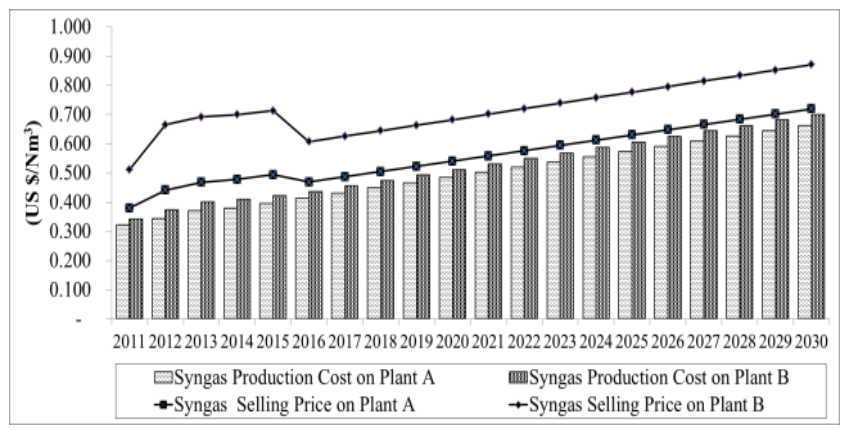

Fig. 3. Syngas production cost and syngas selling price on Plant A and Plant B in period 2011-2030.

With suitable driving mechanism, coal still has great potential as energy source due to its large availability compared to other fossil fuels and coal gasification as promising conversion technology due to the flexible use of its products.

\section{CONCLUSION}

In this paper, economic analysis of coal gasification plant for electricity and thermal energy supplies in Indonesia. Conclusions are made as following:

1) Comparing coal gasifier technology imported from China (Plant A) and from Germany (Plant B), the investment cost (CAPEX) was much lower for Plant A. Due to the higher efficiency of Plant B, the operational cost (OPEX) was not much different.

2) The calculated electricity generation cost are 0.189 and $0.204 \mathrm{US} \$ / \mathrm{kWh}$, electricity selling price are 0.273 and $0.352 \mathrm{US} \$ / \mathrm{kWh}$ and electricity tariff are 0.279 and 0.358 $\mathrm{US} \$ \mathrm{kWh}$ for Plant $\mathrm{A}$ and $\mathrm{B}$, respectively. Thermal energy is supplied as synthetic gas (syngas). The calculated syngas generation cost are 0.322 and 0.340 $\mathrm{US} \$ \mathrm{Nm}^{3}$ and syngas selling price are 0.38 and 0.512 $\mathrm{US} \$ / \mathrm{Nm}^{3}$, for Plant A and $\mathrm{B}$, respectively.

3) Based on the studied scenario, the selling prices of electricity from coal gasification are competitive when compared to that from diesel oil (i.e. $0.375 \mathrm{US} \$ / \mathrm{kWh}$ ) but much less competitive when compared to that natural gas (i.e. $0.0864 \mathrm{US} \$ / \mathrm{kWh}$ ). The selling prices of syngas is also higher than that of LPG (i.e. $0.238 \mathrm{US} \$ / \mathrm{Nm}^{3}$ ).

4) With suitable driving mechanism, coal still has great potential as energy source especially for remote areas due to its large availability compared to other fossil fuels and coal gasification as promising conversion technology due to the flexible use of its products.

\section{ACKNOWLEDGEMENTS}

The authors would like to acknowledge Indonesian Electricity State Enterprise (PLN) in Sanggau Area, PLN Enjiniring, Bukit Asam and Manambang Muara Enim, and The Indonesian Agency for Assessment and Application of Technology (BPPT) for their support to this work.

\section{REFERENCES}

[1] PLN's Statistic 2013, Jakarta, Indonesia, 2013, p. 77

[2] Technical Committee of Energy (PTE), Blue Print of National Energy Management (PEN), Jakarta, Indonesia, 2006, p. 6.

[3] Indonesian Government Regulation, Regulation No.79/2014 about Restriction coal Export Aiming to Fulfill Domestic Demand, Jakarta, Indonesia, 2014

[4] Indonesian Ministry of Energy and Mineral Resource (MEMR) Regulation, Regulation No.1/2012 about the List Power Plant Projects Using Renewable Energies, Coal and Gas, Jakarta, Indonesia, 2012.

[5] PLN Engineering, "The report of PLN engineering's management for third period in 2012," Jakarta, Indonesia, pp. 17-24, 2012.

[6] Chinese Coal Gasification Power Plant, "Technical proposal $6000 \mathrm{KW}$ coal power plant Indonesia and two stage cold coal gas gasifier quotation," Zhejiang, China, 2010.

[7] Germany Coal Gasification Power Plant, "Coal gas power generation for Indonesia factory test report," Overath, Germany, 2012.

[8] Indonesian Government Regulation, Regulation No.36/2008 about Income Tax, Jakarta, Indonesia, 2010.

[9] T. F. Edgar, Coal Processing and Pollution Control, Texas, United States, 1993, p. 58.

[10] Indonesian Directorate General of Mineral and Coal Regulation, Regulation No.644.K/30/DJB/2013 about the Procedure for Coal Decision Cost, Jakarta, Indonesia, 2013.

[11] Indonesian Ministry of Energy and Mineral Resource (MEMR), Handbook of Energy and Economics Statistic Indonesia 2014, Jakarta, Indonesia, 2014

[12] M. S. Peters, K. D. Timmerhaus, and R. E. West, Plant Design and Economic for Chemical Engineers, $5^{\text {th }}$ ed. New York, USA, 2003, ch. 6-9, p. 12 .

[13] W. P. M. van S. Bliek and K. R. Westerterp, Small Industrial-Scale Producer Gas Unit, Amsterdam, Netherland, 1984, vol. 10, p. 352.

[14] H. B. Maynard and W. K. Hodson, Maynard's Industrial Engineering Handbook, $4^{\text {th }}$ ed. New York, United States, 1992, p. 1293.

[15] J. McKetta and W. A. Cunningham, Encyclopedia of Chemical Processing and Design, New York, United States: CRC Press, 1990, pp. 167-169, 173-176.

[16] Coal Gasification Process for Retrofitting Military Central Heating Plants, USACERL Technical Report FE-93/07, USA, 1992.

[17] E. D. Garrett, Chemical Engineering Economics, New York, USA, 1989, p. 354.

[18] A. Pirantiwi, Development $12 \mathrm{~kg}$ LPG Price in Indonesia 2008-2013, Jakarta, Indonesia: PDAT Kompas's Research, p. 3.

[19] T. Sastrawinata, Small Scale Coal Power Plant in Indonesia, APEC, 2001.

[20] R. Sinnot and G. Towler, Chemical Engineering Design, $5^{\text {th }}$ ed. Burlington, USA, 2009, p. 359.

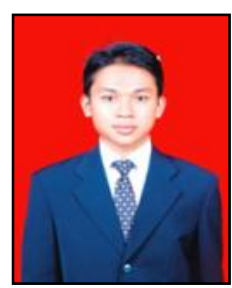

Prima Zuldian was born in Palembang, South Sumatera province, Indonesia on August 9, 1986. Currently, the author is registered as a master degree's student for master engineering degree (M,Eng) between the Joint Graduate School of Energy and Environment (JGSEE), Thailand and University of Sriwijaya, Indonesia in energy field. The author completed his primary until higher education in Palembang in 2004 and bachelor degree of chemical engineering at University of Sriwijaya, in 2010.

Currently he works at the Agency for The Assessment and Application of Technology (BPPT), Directorate of Energy Resources Development Technology in Jakarta and Banten Provinces, Indonesia. Some publications which he had been involved in were The Indonesian Energy Outlook 2010, 2011 and 2012 . 


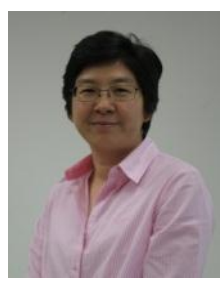

Suneerat (Pipatmanomai) Fukuda was born in Bangkok, Thailand. She received her bachelor degree in chemical technology from Chulalongkorn University, Bangkok, Thailand in 1996, then received her master of science and doctor of philosophy degrees in chemical engineering from Imperial College, London, UK, in 1998 and 2002, respectively. She has worked at the Energy Division of the Joint Graduate School of Energy and Environment, King Mongkut's University of Technology Thonburi in Bangkok, Thailand since 2004 as a lecturer. Currently, she holds an associate professorship as well as management position as the chair of the Energy Division. She has carried out extensive research in the field of solid fuel utilization for energy, from basic science to engineering, including bioenergy and biofuel production, clean coal technology and energy system engineering. She has 47 publications in peer-reviewed journals and conferences of international repute and has involved in a number of international and national projects with high national and industrial impact. She also gives a significant contribution as a peer reviewer for various reputed international journals.

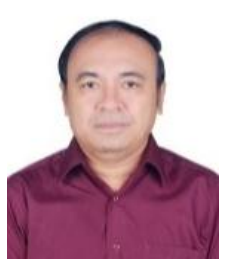

M. Djoni Bustan was born in Palembang, on March 7 , 1956. He completed the bachelor degree of chemical engineering in Sriwijaya University in 1980 . He graduated from Hiroshima University, Japan, in 1986 with a master degree specialized in thermodynamics, and received the doctoral degree from Institute National Polytechnic De Toulose, France, specialized in thermal system analysis in 1992, and this year he got his professorial degree.

$\mathrm{He}$ is currently a lecturer in Post Graduate Program of Sriwijaya University, specializes in energy process and heat transfer. He was involved in the Preliminary Team for the Implementation of National Strategic Excellent Research specialized in energy, in 2005. He was the head of South Sumatera Research Council and a member of National Research Board of Indonesia, in 2006, and one of the Indonesian Presidential Professional staff, in 2008 .

He had been a speaker in seven international conferences, and some of his papers were published in the ASEAN Journal of Chemical Engineering, and Asia-Pacific Journal of Chemical Engineering. 

Solar Energy 
